\title{
PEMBANGUNAN MASYARAKAT SEBAGAI MAKHLUK SOSIAL YANG BERLANDASKAN PANCASILA
}

\author{
${ }^{1)}$ Dia Indriyana, ${ }^{2)}$ Dinda Aulia Putri Jalasenastri, ${ }^{3)}$ Anita Trisiana \\ ${ }^{1,2)}$ Mahasiswa Pendidikan Bahasa Inggris Universitas Slamet Riyadi \\ ${ }^{3)}$ Dosen PPKn Universitas Slamet Riyadi
}

\begin{abstract}
ABSTRAK
Pancasila adalah dasar filsafah Negara Indonesia yang terdapat di dalam pembukaan UUD 1945.Pancasila dijadikan pedoman untuk mengkaji, menganalisis dan memecahkan permasalahan.Pancasila sebagai norma kehidupan masyarakat, bangsa dan Negara. Metode yang digunakan adalah metode deskriptif yaitu metode yang mencari fakta dengan interpretasi yang tepat. Metode ini mempelajari tata cara berlaku dan masalah yang ada dalam masyarakat serta situasi tertentu. Sebagai makhluk sosial, manusia selalu membutuhkan orang lain dan tidak dapat hidup sendiri. Manusia perlu berinteraksi. Tidak hanya interaksi dalam lingkup satu individu dengan individu yang lain, namun juga interaksi yang melibatkan banyak orang seperti masyarakat, bangsa dan negara. Dalam hal ini, potensi yang ada di masyarakat perlu dikembangkan sebagai upaya untuk mencapai suatu perubahan. Pembangunan adalah proses perubahan dimana ada suatu kondisi yang tidak diharapkan menuju kondisi yang lebih lebih baik.Realitas yang dianggap sebagai masalah sosial menjadi pendukung atau memberi dorongan bagi munculnya tindakan perubahan dan perbaikan.Perubahan pola pikir serta ilmu pengetahuan sangat penting dan diperlukan saat ini.Namun, seperti yang kita ketahui bahwa tidak semua upaya perubahan berjalan dengan baik. Banyak masalah sosial yang akan muncul.Masyarakat yang lebihbaik tentunya adalah masyarakat yang kritis, kreatif, memiliki kemampuan untuk menemukan solusi dari masalah yang ada dan selalu mengutamakan kepentingan bersama sesuai dengan pancasila.Pancasila merupakan pedoman serta ciri atau kepribadian bangsa Indonesia.Pancasila menjadi pedoman tingkah laku masyarakat sebagai makhluk sosial.
\end{abstract}

Kata kunci: Makhluk Sosial, Pembangunan, Pancasila 


\begin{abstract}
Pancasila is the basis of the Indonesian philosophy that is found in the opening of the constitution of 1945. Pancasila is a guide for evaluating, analyzing and solving problems. Pancasila as the norm of the lives of society, nations and state.As social creatures, human always needs other people and can not live alone. Human needs to interact. Not only interaction in the individual sphere with another individual but also interaction that involve many people such as society, the nation and state. In that case, the potentials in society needs to be developed as an attempt to achieve a change. Social changes can be about social values, behavioral patterns and social interactions. Development is a process of change where there is a condition that is not expected to be better conditions. A reality that is considered as social problem to be supporting or incitement to the appearance and improvement. Changes in thinking patterns and science are very important and necessary right now. But, as we know that not all the efforts of change is going well. A lot of social problems will arise. A better society is certainly a critical, creative society, having the ability to find a solution to the problem and always keep the interests first in line with pancasila. Pancasila is a hallmark or a nation's personality. Pancasila became the guide of public conduct as social creatures.
\end{abstract}

Keyword :Social Creatures, Development, Pancasila

\section{PENDAHULUAN}

Pembangunan merupakan suatu proses perubahan. Baik perubahan pola pikir, perilaku, maupun perubahan tatanan kehidupan.Secara umum tatanan kehidupan yang baik merupakan suatu kondisi ideal yang didambakan oleh masyarakat. Dimana kebutuhan dapat terpenuhi, adanya rasa tentram dan kondusif agar proses relasi sosial yang adil dapat terwujud.

Manusia sebagai makhluk sosial senantiasa membutuhkan orang lain. Namun, adanya ketidakpahaman masyarakat dengan nilai-nilai yang terkandung dalam pancasila berakibat pada masih banyaknya masyarakat yang selalu mendahulukan kepentingan individu dan kelompoknya diatas kepentingan bersama, bersikap acuh terhadap satu sama lain.

$$
\text { Masyarakat }
$$
cenderung bertahan atau tidak berubah artinya masyarakat menolak nilai baru yang dianggap akan mengubah kehidupannya. Masyarakat hanya akan menerima perubahan yang dianggap menguntungkan untuk diri 
mereka sendiri. Oleh karena itu pemahaman nilai-nilai pancasila sangat dibutuhkan untuk mewujudkan masyarakat yang sejahtera dan sesuai dengan pancasila.

\section{METODE}

Metode yang digunakan dalam artikel ini yaitu metode deskriptif. Metode deskriptif yaitu metode yang mencari fakta dengan interpretasi yang tepat. Metode ini mempelajari tata cara berlaku dan masalah yang ada dalam masyarakat serta situasi tertentu. Begitu juga dengan kegiatan, hubungan, sikap, pandangan serta proses yang sedang berlangsung dan pengaruh yang di dapat dari suatau fenomena. Peneliti bisa saja dengan membandingkan fenomena tertentu sehingga menjadi suatu studi komparatif. Kedudukan fenomena atau faktor serta melihat hubungan antara faktor satu dengan yang lain juga dapat diselidiki dengan metode ini. (Whintney. 1960).

\section{PEMBAHASAN}

\section{Pembangunan Masyarakat}

Pembangunan dilakukan untuk menyejahterakan masyarakat yang sering dijadikan sebagai batu loncatan untuk mendapatkan kesuksesan baik oleh individu, kelompok maupun masyarakat.Pembangunan merupakan usaha untuk meningkatkan segala kemampuan sumber daya manusia maupun sumber daya alam (Sunyoto Usman, 2004: 6).

Tujuan dari pembangunan masyarakat yaitu membentuk dan mengembangkan kekuatan masyarakat dalam mempertahankan hidupnya sendiri dan orang lain yang berupa materiil maupun non-materiil. (Azyumardi Azra, 2000: 137).

$$
\text { Realitas sosial seperti }
$$

pembangunan masyarakat selalu muncul dalam kehidupan.. Realitas pembangunan masyarakat ini dapat dilihat sebagai salah satu proses perubahan sosial. Dari masa ke masa perubahan sosial akan terus berlangsung baik direncanakan maupun tidak direncanakan. Perubahan sosial merupakan sesuatu yang wajar dan alamiah dan dialami setiap masyarakat (Salim,2002:10). Dasar-dasar pemahaman realitas 
pembangunan ini merupakan perubahan sosial yang terdiri dari berbagai teori, prinsip dan kecenderungan umum.

Asas-asas pembangunan masyarakat

a) Asas pembangunan integral

Merupakan pembangunan seimbang dari semua segi masyarakat (pendidikan, perumahan, pertanian, kesehatan, dan lain-lain) agar perkembangan dapat selaras serta tidak berat sebelah.

b) Asas kekuatan sendiri

Tiap-tiap usaha harus didasarkan pada kemampuan dan tidak menunggu pemberian dari pemerintah.

c) Asas permufakatan bersama Usaha pembangunan harus dilaksanakan dengan benar sebagai kebutuhan anggota masyarakat yang bersangkutan.Keputusan untuk menjalankan sesuatu bukan berdasarkan perintah atasan.Namun merupakan keputusan bersama anggota masyarakat.
Seperti yang kita ketahui, pembangunan merupakan suatu proses perubahan.

Bentuk-bentuk perubahan :

1) Perubahan yang dikehendaki yaitu, perubahan yang telah direncanakan oleh agen perubahan (agent of change).

2) Perubahan yang tidak dikehendaki yaitu, dampak dari perubahan yang telah direncanakan.

3) Perubahan kecil yaitu, perubahan yang tidak membawa pengaruh langsung untuk masyarakat seperti perubahan pada unsure struktur sosial.

4) Perubahan besar yaitu, perubahan yang mempengaruhi aspek kehidupan bermasyarakat.

5) Evolusi yaitu perubahan dalam jangka waktu yang lama dari perubahan yang kecil yang saling berhubungan serta saling memengaruhi. 
6) Revolusi yaitu perubahan yang berlangsung dengan cepat yang mrnyangkut sendi pokok kehidupan masyarakat.

Faktor penyebab perubahan :

Menurut Ruswanto ada dua faktor penyebab perubahan sosial yaitu,

A. Faktor dari dalam masyarakat :

1) Pertambahan penduduk

$$
\text { Penduduk yang }
$$

semula hanya terpusat pada lingkungan kerabat kemudian menjadi terpencar dan berorientasi pada pekerjaan karena adanya pertambahan penduduk.

2) Pertentangan dalam masyarakat

Salah satu contohnya seperti latar belakang SARA pada masyarakat yang menyebabkan retaknya persatuan dan kesatuan bangsa.

3) Terjadi pemberontakan Salah satu contohnya yaitu perubahan dalam sistem politik dan larangan ajaran komunis berawal dari adanya pemberontakan G30-S/PKI.
4) Berkurangnya penduduk.

$$
\text { Terjadi kesulitan }
$$

dalam mendapatkan tenaga muda di desa karena adanya urbanisasi (perpindahan penduduk dari desa ke kota).

5) Penemuan baru (inovasi)

$$
\text { Merupakan proses }
$$
sosial yang besar dan terjadi dalam jangka waktu yang tidak terlalu lama.

- Discovery yaitu penemuan unsur kebudayaan yang baru seperti alat ataupun ide yang diciptakan individu atau kelompok.

- Invention yaitu penemuan baru yang telah diakui, diteriama, dan diterapkan dalam masyarakat.

6) Peranan tokoh karismatik

Tokoh yang
membawa pengaruh dalam
perubahan masyarakat.Seperti
Nabi Muhammad SAW yang
membawa pengaruh bagi
umat islam diseluruh dunia
(Soerjono Soekanto, 1990:
351)

B. Faktor dari luar masyarakat : 
1) Pengaruh lingkungan alam.

Keadaan fisik dari

alam seperti kesuburan dan tanah yang tandus membawa pengaruh yang berbeda dalam tingkat kemakmuran masyarakat.

2) Pengaruh kebudayaan masyarakat lain.

Kontak kebudayaan Indonesia dengan kebudayaan barat membawa pengaruh positif seperti transformasi IPTEK.Namun membawa sikap westernis sekelompok masyarakat Indonesia.

Muhamad Iqbal berpendapat bahwa penyebab perubahan sosial meliputi :

1) Innovation (inovasi), merupakan penemuan baru serta pembaruan yang berpengaruh terhadap kondisi individu maupun kelompok masyarakat.

2) Adaptation (adaptasi), berupa penyesuaian secara sosial dan budaya.

3) Adoption (adopsi), merupakan penggunaan penemuan baru yang dapat memudahkan manusia dalam kehidupan sehari-hari dalam bidang teknologi.

Faktor penghambat perubahan

1) Adanya prasangka buruk terhadap hal baru.

2) Terlambatnya perkembangan IPTEK.

3) Sikap fatalistik atau perasaan sangat putus asa dalam segala hal.

4) Hubungan dengan masyarakat lain yang kurang.

5) Hambatan dari faktor kebiasaan.

6) Sikap pesimis.

7) Tertanamnya rasa terhadap kepentingan individual yang dianggap lebih penting dari kepentingan bersama.

\section{Masyarakat Sebagai Makhluk} Sosial

Manusia merupakan makhluk sosial.Manusia disebut sebagai masyarakat dalam konteks sosial.Pada kodratnya manusia adalah makhluk individu dan makhluk sosial. Manusia akan hidup bersama untuk memenuhi kebutuhan jasmaniah maupun kebutuhan rohaniah. Ada dorongan untuk berinteraksi dengan orang 
lainsebagai makhluk sosial.Maksud dari istilah sosial adalah selalu mendahulukan kepentingan bersama atau masyarakat. Dalam arti lain makhluk yang hidup berdampingan serta bermasyarakat. Selama hidupnya manusia tidak akan pernah terlepas dari pengaruh masyarakat. Kepentingan dan kesamaan ciri merupakan alasan seseorang berhubungan dengan orang lain.

Manusia memiliki sifat khas dalam berhubungan dan berinteraksi dengan lebih baik.Salah satunya yaitu kegiatan mendidik. Mendidik merupakan salah satu cara untuk mewujudkan manusia dengan pengetahuan yang luas.

Terdapat nilai atau norma yang dimiliki masyarakat yang mungkin terjalin saat kerja sama antara satu sama lain yang disebut dengan modal sosial. Unsur utama modal sosial yakni apabila diantara satu kelompok dengan yang lain saling percaya pada hubungan sosialnya. Kepercayaan membuat terdorongnya seseorang untuk menggunakan hasil karya orang lain., bahkan timbulnya tindakan yang produktivitas yang saling menguntungkan. Kepercayaan merupakan aspek yang sangat penting yang menimbulkan munculnya modal sosial. Jadi masyarakat senantiasa menjaga komitmen dan kerja sama antara satu sama lain yang merupakan tujuan bersama secara efektif.

Unsur utama modal sosial yang lainnya yaitu unsure reciprocal atau timbal balik. Salah satu contohnya terjadi dalam proses interaksi sosial yakni saling memberi, saling menerima dan saling menbantu. Implemintasinya modal sosial dengan terwujudnya jaminan sosial bagi masyarakat.

Pemanfaatan sumber daya sosial perlu disesuaikan dan ditransformasikan sesuai perkembangan masyarakat. Dahulu, kehidupan masyarakat digambarkan sebagai masyarakat homogen dalam segi mentalitas dan moralitas, mempunyai kepercayaan yang sama, belum mengenal adanya diferensiasi fungsi ataupun pembagian kerja. Namun, saat ini kehidupan masyarakat mulai mengenal diferensiasi serta berbagai variasi meskipun belum cukup tajam seperti : diferensiasi struktural sudah kearah fungsional meskipu belum seperti 
masyarakat industri serta diferensiasi fungsi yang mulai bertambah banyak tidak hanya pada pemisahan unsur yang sama.

Pendidikan merupakan salah satu sarana untuk mencapai kemakmuran serta kenyamanan hidup yang akan membawa manusia menjadi individu berwawasan luas dan berguna dalam kehidupan masyarakat. Dapat diartikan bahwa kehidupan masyarakat juga tergantung dengan pendidikannya. Pendidikan akan membuat manusia lebih melaksanakan norma dengan baik (Trisiana,Anita: 2016).

\section{Pancasila}

\begin{tabular}{llll}
\multicolumn{4}{r}{ Pancasila merupakan dasar } \\
filsafah Negara Indonesia yang \\
terdapat dalam pembukaan
\end{tabular}

1945. Pancasila sebagai norma kehidupan masyarakat, bangsa dan Negara. Pancasila dijadikan pedoman untuk mengkaji, menganalisis dan memecahkan permasalahan. Masyarakat Indonesia senantiasa memerlukan nilai-nilai pada pancasila sebagai suatu pandangan hidupnya sebagai salah satu makhluk ciptaan Tuhan Yang Maha Esa dalam perjuangan untuk mencapai sebuah kehidupan yang mungkin lebih sempurna. Nilai-nilai sosial merupakan suatu tolak ukur kebaikan yang berkaitan dengan halhal yang mendasar di dalam hidup manusia seperti cita-cita yang ingin dicapai.

Nilai moral pancasila yang berakar pada kedudukan kodrat manusia :

1) Nilai Ketuhanan Yang Maha Esa

Senantiasa bertakwa serta beriman kepada Tuhan Yang Maha Esa sesuai dengan apa yang menjadi kepercayaan yang dianut masing-masing individu.Nilai inilah yang menjadi landasan hidup rukun antar masyarakat, bangsa dan Negara.

2) Nilai Kemanusiaan Yang Adil dan Beradap

Manusia sebagai warga Negara harus mengakui adanya persamaan hak, derajat serta kewajiban antara sesama manusia sebagai bukti asas kebersamaan bangsa Indonesia.Perlu menjunjung tinggi persamaan hak, derajat serta kewajiban agar dapat memelihara dan menegakkan kebersamaan.

3) Nilai Persatuan Indonesia 
Manusia sebagai warga Negara harus mengutamakan persatuan dan kesatuan bangsa serta mengutamakan kepentingan dan keselamatan bangsa di atas kepentingan golongan maupun pribadi. Sikap inilah yang menjadikan manusia memiliki kesanggupan dan rasa rela untu berkorban demi kepentingan bersama untuk bangsa dan Negara yang dilandadi oleh adanya rasa cinta terhadap tanah air Indonesia.

4) Nilai Kerakyatan yang Dipimpin Oleh Hikmat Kebijaksanaan dalam

Permusyawaratan/Perwakilan

Manusia sebagai warga negara ataupun warga masyarakat mempunyai kedudukan, hak serta kewajiban yang sama. Harus selalu mengutamakan dan memperhatikan kepentingan Negara maupun masyarakat serta selalu mengedepankan jalan musyawarah untuk mufakat dalam menyekesaikan suatu masalah.

5) Nilai Keadilan Sosial Bagi Seluruh Rakyat Indonesia

Sebagai warga Negara, manusia harus bisa bersama-sama dalam menciptakan suatu keadilan sosial dalam kehidupan bermasyarakat, berbangsa, maupun bernegara.Perlu adanya sikap saling memupuk sikap adil dan menghormatiu antar sesama.

Segala penjabaran norma baik norma hukum, norma moral maupun norma kenegaraan lainnya terdapat dalam pancasila. Sidharta (2003: 3) mengatakan bahwa nilai hukum yang dijiwai pancasila berdasarkan asas semangat kerukunan.Hukum secara langsung berupaya untuk terwujudnya keadilan sosial terhadap masyarakat sebagai satu kesatuan dan memperoleh kesejahteraan baik materiil maupun spiritual yang proporsional.Dalam asas kerukunan terdapat asas kepatutan. Asas ini berisikan tentang tata cara penyelenggaraan hubungan antar masyarakat agar sikap dan perilakunya disesuaikan dengan kenyataan sosial. Perilaku yang tidak merendahkan martabatnya sendiri ataupun orang lain merupakan suatu harapan guna memperhatikan kepantasan dalam terlaksananya hak dan kewajiban. Pancasila berperan dalam mewujudkan ketertiban, kedamaian serta keadilan dengan 
istilah pengayoman (perlindungan) yang tidak hanya bersifat pasif.Menciptakan kondisi serta mendorong masyarakat untuk memanusiakan diri terus menerus.Dalam arti kondisi sosial yang memungkinkan masyarakat diberikan kesempatan yang luas untuk mengembangkan semua potensinya secara utuh, meningkatkan budi pekerti dan citacita moral berdasarkan Ketuhanan Yang Maha Esa.

\section{PENUTUP}

\section{Kesimpulan}

Berdasarkan pembahasan dapat diambil kesimpulan bahwa potensi manusia akan berkembang apabila ia hidup dengan orang lain seperti dalam kehidupan bermasyarakat. Dalam interaksi antar masyarakat, setiap individu akan membawa kepribadian dan identitas diri masing-masing. Hal ini akan menyebabkan terjadinya berbagai konsekuensi tindakan dari masingmasing individu.

Manusia sebagai makhluk sosial yang artinya membutuhkan orang lain dalam mewujudkan kebutuhan serta berpengaruh dalam proses pembangunan. Agar tercapainya tujuan pembangunan perlu adanya orang lain sebagai pendukungnya. Realitas sosial yang muncul di kehidupan masyarakat dilihat sebagai salah satu perubahan.Interaksi sosial selalu mengalami perubahan yang terdiri dari teori, prinsip dan kecenderungan umum.Perubahan ini dapat berupa perubahan pola interaksi, perilaku sosial, serta pola pikir dari masingmasing individu masyarakat kearah yang lebih baik.

Dalam kehidupan bermasyarakat harus memiliki aturan norma agar dapat dijadikan pedoman untuk menjadi manusia yang lebih beradap. Dengan harapan lebih menghargai nilai dan norma yang akan menjadikan mereka pribadi yang lebih baik.Dalam hal ini pancasila menjadi pedoman manusia sebagai makhluk sosial dalam kehidupan bermasyarakat.

\section{Saran}

Berdasarkan simpulan diatas. Berikut saran yang dapat diajukan :

1. Bagi Masyarakat Masyarakat seharusnya selalu menjunjung tinggi nilai-nilai 
pancasila dalam kehidupan

bermasyarakat, berbangsa

dan bernegara.Sebagai

makhluk sosial, sudah

seharusnya setiap individu

saling menghargai.

2. Bagi Pemerintah

Untuk tercapainya suatu perubahan pada masyarakat perlu adanya campur tangan

pemerintah.Pemerintah

seharusnya mengupayakan

ataupun memfasilitasi usaha

perubahan demi terwujudnya

suatu

pembangunan

masyarakat 


\section{DAFTAR PUSTAKA}

Aw, Suranto. (2010). Komunikasi Sosial Budaya. Yogyakarta: Graha Ilmu.

Budhisantosa ,S. (2017). Pancasila Dan Kebangsaan Dalam Masyarakat Majemuk Dengan Keanekaragaman Kebudayaan. Jurnal Ketahanan Nasional.Vol. 7.No. 2.Hal.1537.

Harish, Janani. (2018). Leadership for a New Paradigm in Human Development.Cadmus Journal.Vol. 2.Hal.88-104.

Harish, Janani. (2014). Society and Social Power.Cadmus Journal.Vol. 2.Hal.37-49.

Hedy Shri A, dkk. (2017). Corak Hubungan Sosial Masyarakat Majemuk Di Indonesia Dalam Rangka Pembangunan Nasional.Jurnal Ketahanan Nasional.Vol. 7.No. 2.Hal.39-52.

Kaelan.(2014). Pendidikan Pancasila.Yogyakarta Paradigma.

Mahmud, dkk.(2015). Pendidikan Lingkungan Sosial Budaya. Bandung: PT Remaja Offset.

Soetomo.(2012). Pembangunan Masyarakat Merangkai Sebuah Kerangka.Yogyakarta Pustaka Pelajar.
Sudjana.(2018). Hakikat Adil Dan Makmur Sebagai Landasan Hidup Dalam Mewujudkan Ketahanan Untuk Mencapai Masyarakat Sejahtera Melalui Pembangunan Nasional Berdasarkan Pancasila.Jurnal Ketahanan Nasional.Vol. 24. No 2. Hal.135-151.

Tchurovy, Dimitar. (2015). The New Paradigm of Social Evolution: Modern Society between Hope and Tragedy.Cadmus Journal.Vol. 2.Hal.184-195.

Trisiana,Anita (2016). Pengembanga $n$ Model Pembelajaran Project Citizen untuk Pendidikan Karakter di Sekolah Menengah Atas Surakarta. $\mathrm{PhD}$ thesis, Universitas Sebelas Maret. 
